\title{
LSE Research Online \\ Ivor Sokolić \\ My neighbour, the criminal: how memories of the 1991-1995 conflict in Croatia affect attitudes towards the Serb minority
}

\section{Article (Accepted version) (Refereed)}

Original citation: Sokolić, Ivor (2017) My neighbour, the criminal: how memories of the 1991-1995 conflict in Croatia affect attitudes towards the Serb minority. Nations and Nationalism, 23 (4). pp. 790-814. ISSN $1354-5078$

DOI: $10.1111 /$ nana.12311

(C) 2017 The Author

This version available at: http://eprints.Ise.ac.uk/84966/ Available in LSE Research Online: October 2017

LSE has developed LSE Research Online so that users may access research output of the School. Copyright (C) and Moral Rights for the papers on this site are retained by the individual authors and/or other copyright owners. Users may download and/or print one copy of any article(s) in LSE Research Online to facilitate their private study or for non-commercial research. You may not engage in further distribution of the material or use it for any profit-making activities or any commercial gain. You may freely distribute the URL (http://eprints.Ise.ac.uk) of the LSE Research Online website.

This document is the author's final accepted version of the journal article. There may be differences between this version and the published version. You are advised to consult the publisher's version if you wish to cite from it. 


\title{
My Neighbour, the Criminal: How memories of the 1991-1995 conflict in Croatia affect attitudes towards the Serb minority
}

\begin{abstract}
This paper investigates how Croats view the minority Serb population in Croatia. It is based on focus groups, dyads and interviews conducted in Croatia in 2014 and 2015. Serbs constitute the 'other' to Croatian identity, which is defined primarily through language and religion. The analysis finds that the predominant war narrative related to the 1991-1995 conflict, one of defence against a larger Serbian aggressor, influences both of these notions of identity, as well as perceptions of the Serb minority in the state. Participants displayed contradictory attitudes in a discourse that featured many key facets of the war narrative. Most respondents agreed Serbs should be equal members of Croatian society, but they also did not believe Cyrillic signs should be put up in Vukovar. The introduction of bilingual signs both reduced trust in government institutions and was interpreted as a continued threat against the Croatian people and state.
\end{abstract}


The predominant war narrative of the 1991-1995 conflict in Croatia has become an intrinsic part of how Croats view the Serb minority in Croatia. ${ }^{1}$ According to this narrative, Croatia and Croats were victims of Greater Serbian aggression and fought in self-defence in order to save the Croatian state and nation (Pavlaković 2014: 19). The narrative is nearly universally accepted and it is institutionally inscribed in two parliamentary declarations (The Declaration on the Homeland War from 2000 and the Declaration on Operation Storm from 2006). The key characteristics of this narrative are Croatian defence, survival, struggle and victimhood against a Serb, Serbian or Yugoslav (among a range of terms) aggressor, in a broken Yugoslav system (Banjeglav 2012; Jović 2009; Koren 2011; Pavlaković 2014; Peskin and Boduszynski 2003). Moreover, there exists a notion that the war is not over since to many individuals it continues to form a key part of their lives and issues from it remain unresolved. Many of these issues are defined in relation to Serbs and Serbia. The situation with Cyrillic ${ }^{2}$ signs in Vukovar exemplifies this since it has come to be seen by Croats as an aggression against them, rather than an issue of minority rights. ${ }^{3}$ This article investigates how Croats view Serbs in Croatia and how the war narrative features in this attitude. It looks at how different types of institutions, such as the Church or the government, affected this. These issues in great part define how Serbs make up the 'other' in Croat identity.

Serbs remain the largest ethnic minority in Croatia and make up $4.36 \%$ of the population, down considerably since the 1991 level of $12.2 \%$ and the 1971 level of $14.16 \%$ (Croatian Bureau of Statistics 2011). Moreover, although the numbers remain disputed, 217,000 Serbs were killed in Croatia during the Second World War by the Nazi collaborationism regime (Goldstein 2003: 310). The UN Human Rights Committee expressed concerns in 2015 over the level of discrimination and violence against Serbs and Roma, in particular (United Nations, Office of the High Commissioner for Human Rights 2015). Moreover, Serb returnees continue to struggle to access government programmes aimed at facilitating their return. Most recently, a Council of Europe Report (2016) expressed concern over: the surge of nationalism and political radicalisation having an impact on minority rights, especially in 
war hit areas; the small number of minorities employed in public service; the limited right to use minority languages and scripts in certain locations; the use of hate speech in media and political discourse; and, the public debate concerning minorities being dominated by antiminority rhetoric and prejudice. ${ }^{4}$

The events in Vukovar originated with the 2011 Croatian census, which found that Serbs comprise over one third of the population in Vukovar, thereby requiring bilingual signs in the city. This resulted in a series of demonstrations in Vukovar in late 2013, as well as some other Croatian cities, to protest this move. The initial rally involved over 20,000 individuals, featured slogans such as "VUKOVAR, NE BУKOBAP" and was likened to previous public shows of support for the Croatian generals in Split. The proposed bilingualism frustrated war veterans and many ordinary citizens due to the wartime experience of the city. Signatures were also collected across the country for a referendum to change the law on minority rights and bilingualism.

Identity, ethnic or national, involves both belonging and otherness, 'there is no self without an other; no identity without alterity; no nation without rival foreigners' (Spiering 1999: 153). Individuals are conscious of belonging to an 'ingroup' as opposed to another 'outgroup' and their behaviour is often biased towards the ingroup and against the outgroup (Langston and Peti-Stantić 2014; Oakes 2001; Tajfel 1978). Moreover, stereotypes about the ingroup and outgroups as constituent parts of identity (Joseph 2004: 76). Serbs have composed the 'other' to Croatian identity and President Tuđman argued that this otherness was based on cultural, historical and geographical differences, which he used in his attempt to unify the Croatian people (Bellamy, 2003: 68). ${ }^{6}$ Political elites since then have furthered this image of Serbs as Croatia's 'radical other' and presented them as uncivilised, non-Western and savage (Zambelli 2010: 1664). Unsurprisingly, there is a high degree of xenophobia towards Serbs in Croatia, especially returnees, who are seen as embodying this otherness and the collective guilt of Serbian aggression (Leutloff-Grandits 2008: 151-156). Moreover, by 
showing how the "Other" has throughout history oppressed Croatia and Croats, it was also possible to argue that history was repeating itself (frequently through historical revisionism) and that Croatia must once again defend itself (MacDonald, 2002).

The picture has since then become somewhat ambiguous. For example, in a study focused on the region of Slavonia, Croat respondents were for the most part prepared to reconcile with Serb returnees, other than those who had committed war crimes (Babić 2010: 221). Eastern Slavonia did feature higher tensions than Western Slavonia in this study, due to the severity of the war there, associated war memories and exacerbated present-day ethnic divisions, but primary social connections in local communities were being gradually rebuilt (Babić 2010: 222). The intensity and speed at which this was happening differed to Western Slavonia, but coexistence has once again become a part of local social fabric.

The article is based on semi-structured focus groups, dyads and interviews conducted in three Croatian cities (Zagreb, Sisak and Zadar) and several non-urban locations in 2014 and 2015. Zagreb was used as it is the largest city in Croatia and it remains the political and cultural centre of the country. It also provides an example of a large metropolis that was not on the frontline of the war. Sisak was selected because it was directly affected by the war, a domestic war crimes trial dealt with crimes committed in the city and, as an industrial hub, it has a larger working class population than most cities. Zadar was used since it is in a different region of Croatia than Sisak and was also directly affected by the war. Moreover, the region is known as a hotbed for Croatian right wing, often nationalist, politics. The nonurban locations were determined based on where it was possible to find participants, although an attempt was made (relatively successfully) to keep the locations within a close distance to the three chosen cities, rather than in completely different parts of Croatia.

The groups were organised with middle and high school history teachers, members of smaller war veterans' associations and pensioners. Teachers were selected since they hold 
a key role in transmitting norms and narratives to younger generations, war veterans since they form a highly influential part of Croatian civil society and pensioners since they had lived through several different types of regimes. Ideally, a focus group was held with each target segment, however, this was not always possible to organise. Three groups (nonurban teachers; non-urban war veterans Slavonia and Zagreb teachers) were, therefore, dyads that were supplemented with further individual interviews. In total 13 focus groups and dyads, with a further four individual interviews, were held with 52 individuals (Figure 1 provides an overview of these). Follow-up interviews were used, when possible to alleviate the risk of the social context of the focus groups from affecting the data, and they were a means to further explore the most interesting opinions expressed.

Figure 1. Overview of focus groups. ${ }^{7}$

\begin{tabular}{cccc} 
Location & $\begin{array}{c}\text { Target } \\
\text { segment }\end{array}$ & $\begin{array}{c}\text { Number of } \\
\text { participants }\end{array}$ & $\begin{array}{c}\text { Number of follow-up } \\
\text { interviews }\end{array}$ \\
\hline Zagreb & Pensioners & 4 & 2 \\
Zagreb & War veterans & 4 & 2 \\
Zagreb & Teachers & $2 ; 1 ; 1$ & 0 \\
\hline Zadar & Pensioners & 4 & 0 \\
Zadar & War veterans & 6 & 2 \\
Zadar & Teachers & 3 & 1 \\
Sisak & Pensioners & 5 & 2 \\
Sisak & War veterans & 3 & 0 \\
Sisak & Teachers & 3 & 2 \\
Non-urban & Pensioners & 5 & 1 \\
Non-urban & War veterans & 5 & 0 \\
(Banovina) & & & 0 \\
Non-urban & War veterans & 2 & \\
(Slavonia) & Teachers & $2 ; 1 ;$ & \\
Non-urban & Tan & & \\
\hline
\end{tabular}


Moreover, a brief survey was handed out to participants prior to each session to allow for comparison to nationally representative survey results. Focus groups were an appropriate primary methodological approach for this type of study since they are good at tackling abstract concepts and investigating issues that could be illuminated by the display of everyday social and cultural norms (Lewis, 2003: 60). They do not "force" opinions on individuals (such as surveys may do) and they strongly reflect the independence of human opinion by further removing the interviewer from the study (compared to individual interviews) and by focusing on social context, where opinion tends to be created, thereby increasing external validity (Söderström, 2010: 4). While focus groups allowed for an effective exploration of narratives and opinions that become more apparent through social interaction, their results are limited since they are not representative of the whole population. The results presented here, when not supported by nationally representative data, highlight only how one small segment of the Croatian public construct their view of Croatian Serbs.

Participants in this study differentiated with Serbs predominantly in terms of religion and language. That is not to say that these are the only factors in defining modern, post-war Croatian identity, since the legacy of the Second World War and communism also contribute strongly to the Croatian sense of differentiation with Serbs. These different memories and associated debates have polarised Croatian society and more recent events such as the shouting of "Za dom, spremni" at football matches has highlighted this (Brentin 2016; Pavlaković 2008). ${ }^{8}$ Moreover, human rights abuses from the communist period have been presented as attacks by one ethnicity on another and have never been analysed in a political vacuum, thereby being easily appropriated for nationalistic mobilisation (Subotić 2015).

National identity in Croatia is, nevertheless, strongly based on religion (Babić 2010; Smith 1991). Throughout the fieldwork the notion of Croat Catholicism was commonly juxtaposed with Serb Orthodox Christianity. As much as Croats identified themselves as Catholics, they equally strongly identified Serbs as Orthodox. The importance of Catholicism to Croatian 
identity has been observed among elites and Prcela (2009: 211) has even argued that it has been overlooked as a factor in Croatian identity. ${ }^{9}$ This identification stems from the 1945 1990 period, when Croatian Catholicism and Croatian national identity merged, as the Church presented itself as the only defender of the Croatian people's collective identity (Jakelić 2010: 118). In Croatia, as well as in Bosnia-Herzegovina, Catholicism became an identity marker for Croats (Sells 2003). It became collectivistic and public; emphasised tradition and ascription; and, defined group boundaries towards the 'other' (Casanova 1994: 217; Jakelić 2010: 197). ${ }^{10}$ During the Homeland War, many volunteers in the Croatian Army saw military deployment as more than just their national duty, but as a religious calling to defend Croatia and in some rural areas facets of Catholicism continue to provide a basis for resistance to centralisation and economic change (Schäuble 2014). This union is probably best exemplified in the expression "bog $i$ hrvati" (God and the Croats) that is built on a shared Croat feeling of suffering (Schäuble 2014: 262). Today, these elements are recurring features in political speeches, religious sermons and in public discourse more broadly.

Language is seen as fundamentally linked with the history of the Croatian people and language is another large differentiator between Serbs and Croats (Fishman 2006). How people identify themselves is in many ways language and culture specific, so identity can be viewed as a key function of language, equal to those of representation and communication (Joseph 2004). In order to legitimise modern Croatian language (especially as a language planning project) and a distinct Croatian national identity, Croatian linguistic identity has been presented as reaching far into the past (Langston and Peti-Stantić 2014: 45). The aims of language planning in Croatia since the 1990s have been exclusively symbolic in order to enhance this identity, in large part because ethnic foundations and identities in the region have been so hotly contested over time ( ibid. 2014: 57). Language policy was used exclusively in the service of national projects and purity of the language was argued to be essential for the survival of the narod (Kordić 2010: 9). ${ }^{11}$ This was the case not only in Croatia, but in the region as a whole. Elites in the region believed it to be important for each 
nation to have its own language in order to differentiate it from other nations (ibid. 2010: 167). Language purism was the consequence of nationalist understandings of language. In the 1990s, the HDZ (Hrvatska Demokratska Zajednica, or Croatian Democratic Union, is the largest Croatian right wing party) became an active agent of language change since they saw language as the main point of differentiation with other Balkan nations, especially Serbs (Bellamy 2003: 146). In an effort to legitimise the Croatian nation, an attempt was made to erase anything from the language that could associate or remind Croats of their shared past with Serbs (Richter Malabotta 2004: 80). Croatian and Serbian were now different languages and if this difference was not visible, then it had to become so (Kordić 2010: 47).

Langston and Peti-Stantić (2014), however, argue that in Croatia the government itself has not been the primary vehicle of language change, instead this was achieved through nongovernmental institutions with similar goals, but greater ambitions. The government rarely seemed eager or willing to introduce legislation or regulations to control language policies, even when the HDZ was in power (Langston and Peti-Stantić 2014: 145). ${ }^{12}$ Laws that did and do exist were rarely enforced and allowed for exceptions, while even less was done regarding the norms of the language (ibid.: 145). Institutions that have been actively involved in this process and that propagated language planning most successfully functioned in a similar way to language academies in other states, both before and after independence (ibid.: 171). These primarily included but are not limited to the Croatian Academy of Sciences and Arts (Hrvatska akademija znanosti i umjetnosti or HAZU), the Council for the Norms of the Croatia Standard Language (Vijeće za normu hrvatskog standardnog jezika), the Institute for the Croatian Language and Linguistics (Institut za hrvatski jezik i jezikoslovlje or IHJJ) and Matica Hrvatska. These are not strictly government institutions, but they do all have significant connections (institutional or financial) to the state, so they do not form a part of civil society either. The government thereby did influence language change through sponsorship of practice rather than by law. The paradox here is that the reason that the issue of a 'minority language' has arisen in Vukovar at all is because Croatian as the official 
state language has been defined by law and, therefore, defined Serbian as a different language in need of protection. This would not be the case if the law regarded the two as different variants of the same language, since there would be no argument for the representation of multiple languages.

In the 1990s the above-mentioned institutions started to encourage an exclusive view of the Croatian standard language that actively looked to eliminate anything related to the 'East' (Langston and Peti-Stantić 2014: 277). This exclusivity defined Croatian identity based on religion (Western Christian and Catholic), language (Croatian and not Serbian) and alphabet (strictly not Serbian Cyrillic). Croatian alphabets were defined as Latin, Glagolitic and Croatian Cyrillic (Horvat 2009: 18). ${ }^{13}$ HAZU even complained in 2007 to the ICTY about their reports intended for Croatia being written in Serbian, along a range of other complaints to the European Union and Western European universities (HAZU 2007). The HAZU called on the government to take more action in order to prevent Europe from introducing a single regional language for Croatia, Serbia and Montenegro. This can be interpreted as reflecting either the Croatian public's or elite's fear that Europe and the West were treating Croatia as a part of an inferior region together with its neighbours. Whose fear it represents is debatable and indicative of the strange position of HAZU, since they and other similar institutions occupy a grey area between government institutions and civil society.

These notions of identity sit alongside the dominant war narrative, which frames the relationship as one of aggressor and victim. In this sense, the Serbian Orthodox Church is seen as inherently aggressive, as opposed to the forgiving and compassionate Roman Catholic Church in Croatia. The Serb community is seen as taking advantage of their unique status in Croatia, granted to them by an open multi-ethnic state. These attitudes, however, feature a range of contradictions. The situation with Cyrillic in Vukovar, discussed at the end of this paper, exemplifies this best. The Serb community feels the effect of these discourses, since they are seen as undeserving of some of the rights granted to them by the Croatian 
state. The implications of this can be exacerbated during turbulent times, such as war, where ingroup and outgroup relations are potentially dangerous and even a matter of life and death (Dugandžija 2006). They become a matter of self-defence and, especially because of this notion, in Croatia they can be related to the feeling that the war is not over. 


\section{Contradictory attitudes towards minorities}

Survey results on attitudes towards minorities in Croatia are ambiguous and point to a generally positive view of them, whereas the focus group and interview data point to a far more pessimistic view of the Serb minority specifically. Three general trends are apparent in surveys: that the Croatian public claims to view ethnic minorities in Croatia favourably, that they rank harmony between ethnic minorities as a low priority and that they do not believe localities with significant Serb populations should have signs in Cyrillic. Participants in this study reflected this, when asked to rate the importance of three principles of the Croatian constitution, ethnic equality scored lowest. Surveys by llišin (2011) conducted in 1999 and 2004 support these findings (Figure 2).

Figure 2. How important do you believe the following principles of the Croatian constitution to be?

\begin{tabular}{|c|c|c|c|}
\hline \multirow[t]{2}{*}{ Constitutional Values } & 1999 & \multicolumn{2}{|c|}{2004} \\
\hline & $\begin{array}{l}\text { Young } \\
\text { people }\end{array}$ & $\begin{array}{l}\text { Young } \\
\text { people }\end{array}$ & Elderly \\
\hline Freedom & (1) 91 & (1) 94 & (1) 95 \\
\hline Respecting human rights & (2) 88 & (2) 92 & (2) 94 \\
\hline Equality & (4) 74 & (3) 86 & (4) 87 \\
\hline Social justice & (3) 76 & (4) 82 & (3) 89 \\
\hline Maintenance of the environment & (5) 73 & (5) 79 & (6) 83 \\
\hline
\end{tabular}




$$
\text { Gender equality }
$$

Peace building

Integrity of ownership rights

Ethnic equality

Rule of law

Democratic and multi-party

system
(6) 79

(7) 80

(6) 67

(7) 76

(8) 80
(10) 55

(9) 58

(9) 71

(10) 75

(8) $73 \quad$ (5) 86

(7) 65

(9) 71

(10) 64

(9) 79

(8) 61

(11) 58

(11) 72

\section{Source: llišin (2011)}

The Ipsos Puls (2012) survey found that the Croatian public generally looked favourably on different ethnicities living in Croatia (Figure 3) but less favourably on coming into familiar contact with members of those ethnicities (Figure 4). 
Figure 3. Members of different ethnicities frequently come into close interpersonal contact. What form of interpersonal contact would you find acceptable with the following groups? To live in Croatia.

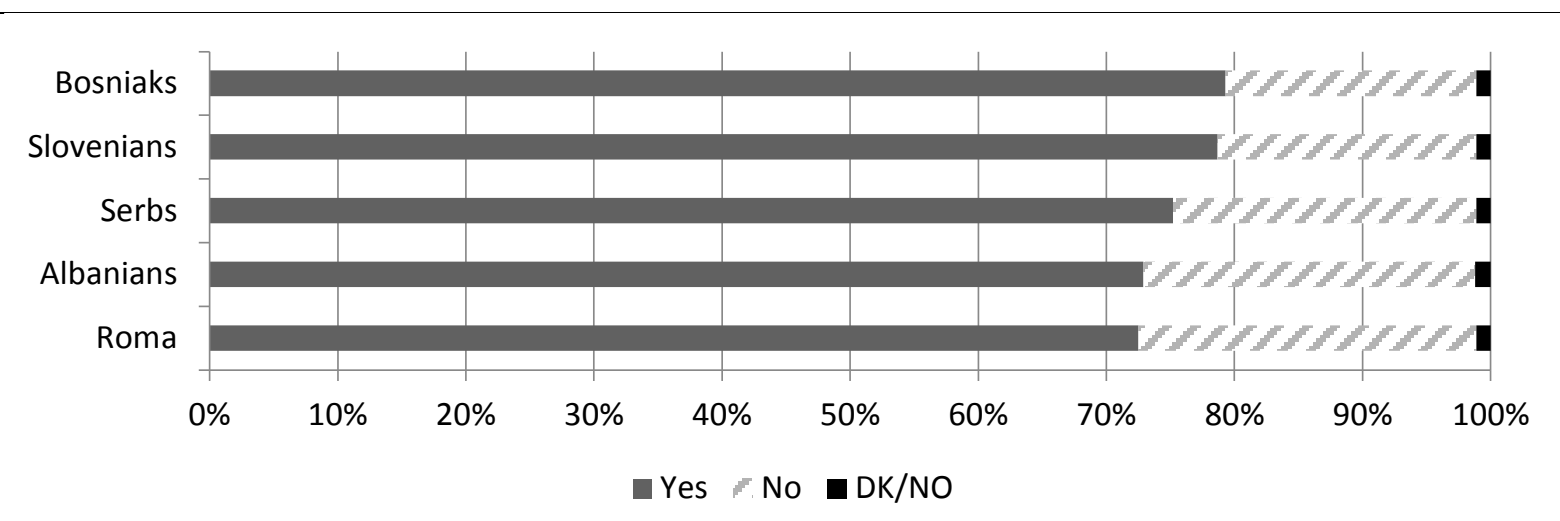

Source: Ipsos Puls (2012)

Figure 4. Members of different ethnicities frequently come into close interpersonal contact. What form of interpersonal contact would you find acceptable with the following groups? To be a member of your family.

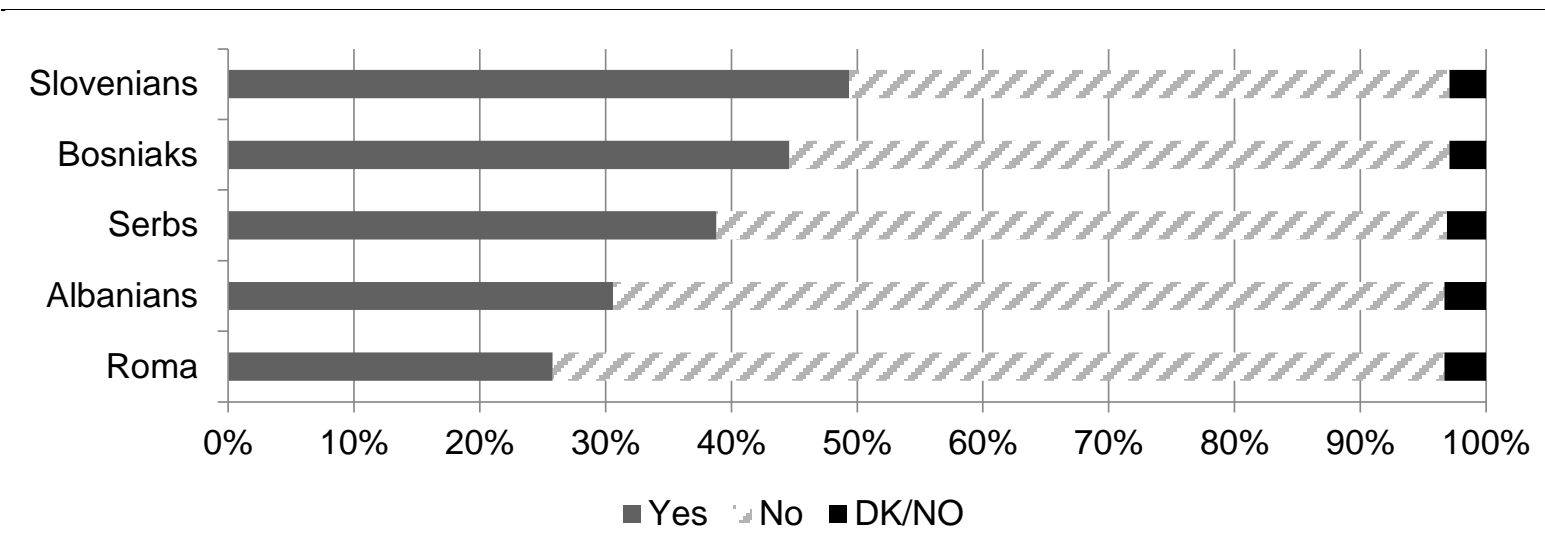

Source: Ipsos Puls (2012)

What is striking here is not only the negative opinion of Serbs, but of all ethnicities listed. This calls into question the centrality of Serbs, they appear to be liked and disliked as much as other groups. Participants in this study also displayed ambiguous opinions in the survey element. For example, a survey question regarding Serb minority involvement in the 
development of museums dealing with $20^{\text {th }}$ century Croatian history received a generally positive response, but as the below passages will show, strong negative opinions of the minority were present in focus groups, dyads and interviews. This presents another instance of contradiction where norms of inclusivity, expressed by the public, meet a relatively strong war narrative by which issues of minority rights are instead interpreted as an attack on the Croatian people. Moreover, this highlights the conflicting nature of quantitative and qualitative research methods. Quantitative methods can miss narratives that influence behaviour and individuals may be aware of the social expectations to express openness towards Serbs, although they may not act consistently with this opinion in specific situations (such as Cyrillic in Vukovar).

\section{The Serb minority}

Throughout all of the group discussions related to Serbs in Croatia, war veterans and pensioners were exceptionally vocal, while teachers were quiet. The two target segments spent much time discussing the Orthodox Church and the current position of Serbs in Croatia, in particular. Across all groups, however, discussion centred on the war and the role of the Croatian Serbs in it. Much of this focused on the notion that there was no expulsion of Serbs from Croatia (that they left willingly), that they committed more crimes than Croats and that they knew the war was coming and were, therefore, prepared for it. ${ }^{14}$

All groups felt that Serbs and Serbia had not punished their own criminals the way that Croatia had. Various reasons were given for this, from the strength of nationalism in Serbia to conspiracy theories concerning political elites in the region as a whole:

ZA.T.2 - The problem in Serbia is that it has not come to terms with the role she has played [in the war] and now the current government is quite radically 
nationalistic... (pauses) They allow them to be Greater Serbs, chetniks, nationalists, this and that (follow-up interview with Zadar teacher).

ZG.V.4 - Courts in Serbia have not convicted a single officer. They have sentenced a few regular soldiers, volunteers. Courts in Croatia have convicted highly ranked officers from colonels to generals in the Croatian Army (focus group with Zagreb war veterans).

There was, however, disagreement over exactly what was necessary by the Serb side to be seen as trying their own. In the below passage, one participant felt that Serbia was doing enough by cooperating with the ICTY, which another participant saw as a defence of Serbian aggression. Accusations such as this can limit the potential for constructive debate about interethnic relations or even the past more generally:

ZG.P.3 - Who sent [Milošević] to The Hague?

ZG.P.2 - That is what I wanted to say, in the end the Serbs sent him.

ZG.P.1 - Well yes, they sent him, they had to.

ZG.P.3 - What more do you want?

ZG.P.2 - Do not argue.

ZG.P.1 - You are defending Milošević and the Serbian aggression. 
ZG.P.3 - No!

ZG.P.1 - If I need to discuss this with you.

ZG.P.3 (interrupts) - This is our Croatian politics.

ZG.P.1 - Do not teach me about Croatian politics, I have seen it all up close.

ZG.P.3 - Do not teach me, I am older and I took part in the Second World War! I can read between the lines quite well (focus group with Zagreb pensioners).

Pensioners and war veterans felt that Serbs, as an ethnicity, were inherently aggressive and hateful. Again, this was closely connected to the predominant war narrative and the feeling that the war is not over. In extreme cases, Serbs were seen as teaching their children to hate. This was compared to the peaceful nature of the Croat people:

NU.P.4 - Us Croats are that kind of narod. Even though the wounds are deep and it is difficult for someone who has lost someone, but reconciliation will come from our side before it comes from theirs. Although they maybe say it is not so. They are simply that kind of narod.

NU.P.1 - They would wage war now.

NU.P. 4 - Yes, they are like that. It is in their blood.

NU.P.2 - Since they teach them to hate (focus group with non-urban pensioners). 
This is closely related to how respondents viewed the Catholic and Orthodox Churches, the former as peaceful and the latter as aggressive (discussed below). It is also linked to the general view of the Greater Serbian plan. Respondents believed that 'Greater Serbia is an idea that lives on and will live on in many Serbs and generations to come' (focus group with Zadar war veterans) and attempts to introduce Cyrillic signs in in Vukovar were at times seen as an attempt to implement this plan.

Not all comments directed at the Croatian Serb community were negative. Since discussions predominantly focussed on the Homeland War, there were admissions across all groups that Serbs, although only a minority, did fight on the Croatian side in the war. Croatia was by some also seen as the homeland of the Serbs. Teachers generally felt that it was hard for Serbs during the war, while war veterans considered 'good' Serbs to be the ones that fought on the Croatian side and used stories about their neighbours to show evidence of this (including how they personally helped each other during the war). This is indicative of the strength of social ties in the local community and the results have been replicated in survey research (Babić 2010). Despite so many communities being destroyed, neighbours did protect each other and such memories have survived through the war narrative. This provides hope for the rebuilding of local communities, especially in war hit areas, where inter-ethnic tensions are particularly high.

All target segments believed that Serbs overall were manipulated by Greater Serbian politics. This creates yet another contradiction with the war narrative's notion of exclusively Croat victimhood and Serb aggression. Instead it reformulates it into Serbian state aggression and manipulation of all ethnicities in Croatia, painting them all as victims:

SI.T.1 - The Serb minority currently has a very interesting situation. I think they were manipulated in this whole story. They were a tool of Greater Serbian 
politics and Milošević used them for his own interests (focus group with Sisak teachers).

On the other hand, the Zadar teachers, for example, thought that Serbs considered themselves to be eternal victims and that they were only affected by the war on the frontline. Serb returnees were, however, only brought up and discussed by war veterans, who debated the topic at length. They universally saw them as accomplices to war criminals:

NU.V.5 - So I told [a Serb returnee], this war criminal, I told him 'in you, in every person who returns from Serbia, I see the potential killer of my husband.' He responded 'please madam do not be like that.' So I responded, 'until you tell me who killed my husband, I have the right to think so. I can walk through the town with my head raised high. I have the right to say this. You are the killer of my husband until you reveal who actually is' (focus group with non-urban war veterans Banovina).

To many in Croatia, Serbs are seen as the embodiment of collective Serbian guilt and collective Croatian suffering (Leutloff-Grandits 2008: 151-156). Individuals have all too frequently employed notions of collective guilt, especially since guilt has not been individualised to any significant extent. Moreover, the previously cited Babić (2010: 137) survey found that a majority of the public was only prepared to forgive Serbs who were not. The combined implication of this is that, if many Serbs are seen as criminals due to their ethnicity (especially returnees), then readiness for forgiveness can be interpreted as low in Croatia. 
National and ethnic identity in Croatia is closely linked to religion and the Catholic and Orthodox churches featured in all group discussions. They were discussed as a source of information on the war and the Catholic Church specifically was seen as educational and reliable. For example, a non-urban teacher believed the Church to be more consistent than any state, since it had been with the Croatian narod for 13 centuries. In many instances, however, the topic was laughed off.

The two churches came up in other parts of discussions as well. These can be divided into four separate categories: opinions about both overall; the Church as a key component of identity; the Catholic church specifically as forgiving; and, the Orthodox church specifically as aggressive. Overall teachers saw all Churches as politically biased (towards the right), political or corrupt, although this did feature some disagreement within groups. Pensioners also discussed the Church, but they were not as critical, while war veterans generally avoided the topic:

ZA.T.2 - The Islamic community, the Serbian Orthodox Church and the Catholic Church, they all strictly adhere to.

ZA.T.1 (interrupts) - Their Church.

ZA.T.2 - Their flock (laughs). And the innocence of their own narod (focus group with Zadar teachers).

NU.T.2 - They are politically right leaning, which is what Churches on these territories have traditionally been, since the time of the Turks (interview with nonurban teacher). 
ZG.P.4 - The Church is all right but it cannot contradict what the constitution tells it. It has a religious function and that function it has to do. It cannot run politics.

ZG.P.1 - And it does not run politics. The parliament runs politics, the President.

ZG.P.4 - I am just saying my opinion, you can have yours.

ZG.P.2 - I sometimes talk to some people who are quite religious, I for one am not, but people are unhappy about how much the church is meddling in politics, in things that are not really its business, its job. As I said earlier, before you (ZG.P.1) arrived, this Latin-American Catholic Church is actually on the side of the poor, but ours was in an alliance with the HDZ. It never condemned the theft, the cheating, nothing. They only talk like you (ZG.P.1), about how communists or criminals are in power. I do not think this is the role of the church. It should deal with religious questions. That is my opinion.

ZG.P.1 - Do you know who defends the poor here? Who feeds the poor in soup kitchens?

ZG.P.2 - I know it is the Church, but they also receive donations from the state.

ZG.P.1 - Many do, even civil society organisations.

ZG.P.3 - Have you (ZG.P.1) looked at the treaty between the Vatican and our Church? Do you know how many billions are tied into it? 
ZG.P.1 - I do not.

ZG.P.3 - Do you know how many churches have been built? How much they were shot at?

Moderator interrupts to calm participants down (focus group with Zagreb pensioners).

The last passage highlights the political associations that are at times made with the Catholic Church in Croatia, as well as the potential for disagreement associated with it. The common dissenting view to the above was that the Church has a role, but not a political one. Groups that on the whole disagreed with the above views thought that the role of the Church was purely spiritual:

SI.T.1 - The Church is concerned with spiritual work and not political.

SI.T.2 - And charity.

All laugh (focus group with Sisak teachers).

SI.V.2 - The Church talks about the Lord. And to have faith in the Lord. Not in Milanović. ${ }^{15}$ In him I have no faith. But in Him above I believe. That is what the Church says (focus group with Sisak war veterans). 
The Church was seen as identifying ethnicity in a number of ways. War veterans especially, but not exclusively, did not consider only Croatia and the Croat narod to have been attacked, but also the Catholic Church. On the other hand they used the term Serbs (Srbi) and Orthodox Christian (pravoslavci) interchangeably to refer to Croatian Serbs:

NU.V.3 - For [the murder of] my parents Tarbuk gave the order. The Serb, Orthodox, leader (focus group with non-urban war veterans Banovina).

SI.V.2 - People of the Orthodox faith, Serbs, were informed when to leave before the artillery fire started (focus group with Sisak war veterans).

NU.P.3 - The Church protected its Catholic narod. It knew who attacked the Catholics (focus group with non-urban pensioners).

NU2.V.2 - Today they talk about Serb villages, but these are not Serb villages, but Croatian villages with Orthodox inhabitants (dyad with non-urban war veterans Slavonia).

War veterans and pensioners saw the Catholic Church as forgiving and, therefore, Croats as a forgiving narod. This notion came up exclusively in a spontaneous fashion in those groups and never came up with teachers. Forgiveness was discussed through the use of Catholic 
symbols and language. Moreover, the topic was frequently associated with reconciliation in the region:

ZA.V.4 - In our Catholic country they say that, in order to forgive someone, that someone has to ask for forgiveness. They have to be aware that they sinned. If I hurt someone, who will forgive me anything if I am not first aware that I have hurt them. Only then can I ask them for forgiveness. I also need to repent and be aware that I have truly hurt them and I never want to do that again. [...] If someone truly apologised to me, maybe I would have that feeling. They have repented and I will forgive them.

ZA.V.3 - You would, because you are Catholic (focus group with Zadar war veterans).

NU.P.3 - I am a believer. How can I forgive a criminal who does not seek forgiveness? This is a question of faith (focus group with non-urban pensioners).

This has the implication that forgiveness, in the eyes of these individuals, is interpreted as religious and specifically Catholic. The would-be sinner must, therefore, ask for it. Given there is a slight preponderance of citizens who believe that the Catholic Church is the predominant moral authority in Croatia (41 per cent agree versus 33 per cent who disagree), this can have far reaching consequences (Figure 5).

Figure 5. The Catholic Church is the moral authority whose opinions should be adhered to by all citizens. 


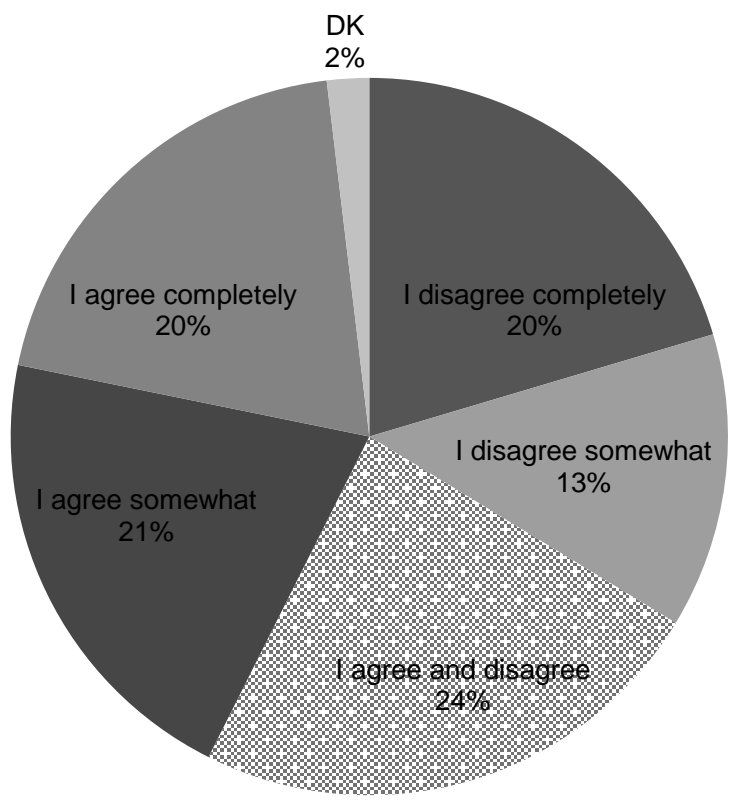

Source: Ipsos Puls (2012)

Whereas only some target segments saw forgiveness as exclusively Catholic or Croat, there was much wider agreement across groups that the Orthodox Church was inherently aggressive. Consequently, there was consensus that the Orthodox Church was involved in the war, directly or indirectly. For example, the Zadar war veterans described coming across Orthodox Churches being used as ammunition storage and a non-urban teacher noted, 'I know the role of the Orthodox Church in the war, it is well known' (interview with non-urban teacher).

\section{Rights for all, but not for them (yet): Serb minority rights}

The special place that the Serb minority holds in Croatia, due to the legacy of the war and the large size of it, was reflected in discussions. Respondents felt that the minority was unique and that it received more rights than other minorities, as well as more rights than Croats in Serbia. The Serb minority was considered unique for a range of reasons: for 
getting special treatment as victims; for their perceived self-imposed segregation; for having to suffer for others' crimes; due to the Law of General Pardon (Narodne Novine 1996); ${ }^{16}$ and so on:

NU.T.1 - I think that today, some 15 years since Operation Storm ${ }^{17}$, they are given such rights and benefits that barely any other minority gets in Croatia (interview with non-urban teacher).

SI.T.2 - We cannot talk about any kind of reconciliation because [the Serbs] are equal citizens of the Republic of Croatia. No one belittles them. Just read an issue of the Serb Novosti, ${ }^{18}$ by the Serb National Council, and you will see what kind of articles are put in there. Can you in any other country write such articles about the country you live in, to smear it, and to still receive funds from the government (focus group with Sisak teachers)?

Passages such as these were common. Veterans complained a great deal about the Law of General Pardon, which they felt gave Serbs special rights, while on the other hand teachers felt that the general Serb population was unique in that a few 'bad apples' had made it difficult for the whole ethnicity to live in Croatia. Generally, however, as in the above passages the ethnic group was often compared to others, especially Italians in Istria:

NU.P.5 - Because they did not stab the Croatian man in the heart or the back. No Croats attacked these poor Serbs, but they attacked us. But with the Italians it was different. When I was in the army, I was told not to sing the songs about our conquest of Trieste. And we gave Trieste back. There is no more war. In Istria there are many Italians. But they have not hurt Croatia in any way, but the 
Serbs wanted to put all of Croatia under the boot (focus group with non-urban pensioners).

At times the position of the Serb minority in Croatia was compared to the Croat minority in Serbia and, again, there was a feeling that Croats were worse off than their Serb counterparts. These comparisons between the Serb minority and other minorities led to a feeling that the Serb minority should not, but does, receive more rights than other minorities. The reasons for this can be divided into four broad categories, each of which features many examples. First, because of what they have done and the legacy of that, so they do not deserve more rights until the country is de-mined or the missing persons are found. Second, because of what they do today, such as voting based on ethnicity. Third, because of what they may do in the future, for example to attack once again (this is connected to the notion that the war is not over). Finally, they should not receive more rights because Croats in Serbia do not.

\section{Cyrillic}

The issue of Cyrillic signs in Vukovar illustrates the inherent contradictions present in how Croatia and Croats deal with the Serb minority in the country. While nearly all respondents felt that Serbs should have the right to Cyrillic signs, they also felt that it was too soon to put them up in Vukovar. No date was, however, given for when the right time might be. While the Serb minority was for a variety of reasons seen as undeserving of this right, all segments agreed that the government created the issue in the first place. Survey results point to similarly contradictory outlooks. 
Across a range of longitudinal measures, attitudes towards ethnic minorities can be interpreted as open and positive. The Kolstø (2011) survey asked a range of questions related to this topic and found that:

- Ethnic and civic identity were of nearly equal importance, although civic identity ranked higher than ethnic.

- Respondents felt they had the most in common with inhabitants of Croatia, regardless of ethnicity, rather than members of their ethnicity living abroad.

- There was some disagreement over whether ethnicities in Croatia were treated equally (44.3 per cent felt they were, 45.7 per cent felt they were not), although this does not indicate if respondents were unhappy with how Serbs, Croats or any other ethnicity were treated. Results from focus groups and interviews in this study indicate that it may be the case that Croats are being seen as treated unfairly. On the other hand, the regions that felt strongest that treatment was unequal (and therefore answered 'no') were Zagreb, Hrvatsko Primorje, Gorski Kotar, Rijeka and Istria, regions that also displayed the most openness towards Croatian Serbs in the rest of the survey. Slavonia, which on the other hand did not display this, featured the most respondents who felt that treatment was equal. Babić's (2010) longitudinal results further support this difference between the regions.

- Both majority and minority groups were strongly (79.8 per cent) seen as deserving equal rights. In other words, that no one deserved special rights.

- For the most part interethnic relations were regarded as positive or at the very least rarely negative (Figure 6). 
Figure 6. How do you evaluate interethnic relations in Croatia. Do you think they are...

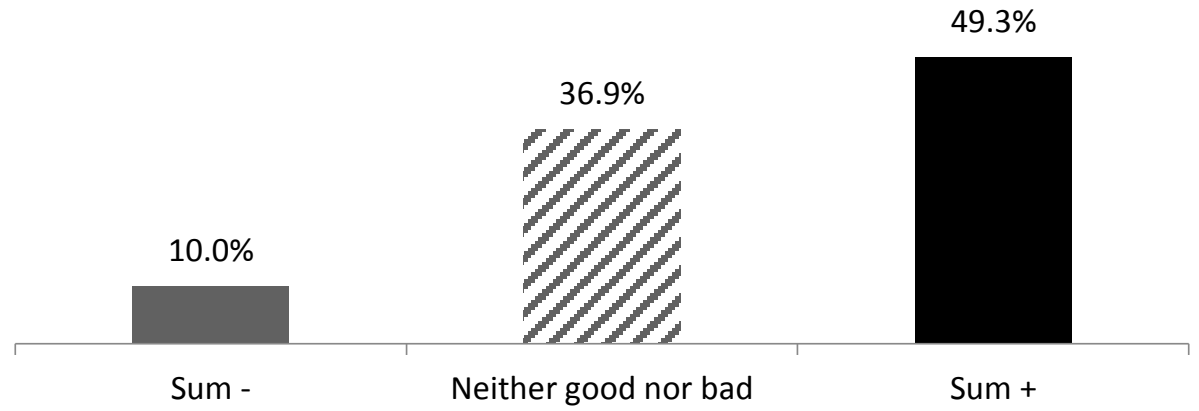

Source: Ipsos Puls (2012)

- Interethnic relations were also seen as having improved in the last ten years (Figure 7).

Figure 7. How do you compare current interethnic relations in Croatia compared to ten years ago? Are they now...

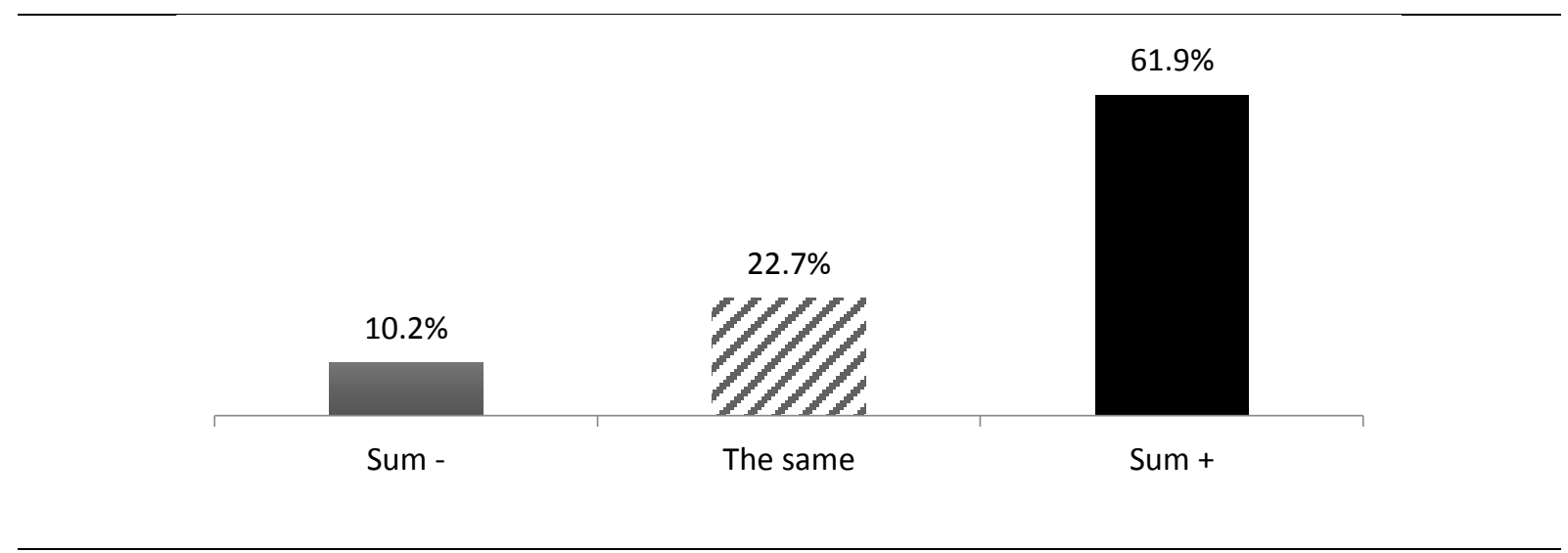

Source: Ipsos Puls (2012)

- The Ipsos Puls (2012) survey also found that respondents overwhelmingly felt that ethnicities should not live alone in their own states.

The above stand in stark contrast to the strong objection to Cyrillic signs in Croatia. The same Kolstø (2011) survey found that respondents were predominantly opposed to the 
introduction of such signs in villages and towns with significant Serb populations (Figure 8). Participants in this study reflected this nearly universally.

Figure 8. Do you think that the names of villages and towns with significant Serb populations should be also written in Cyrillic?

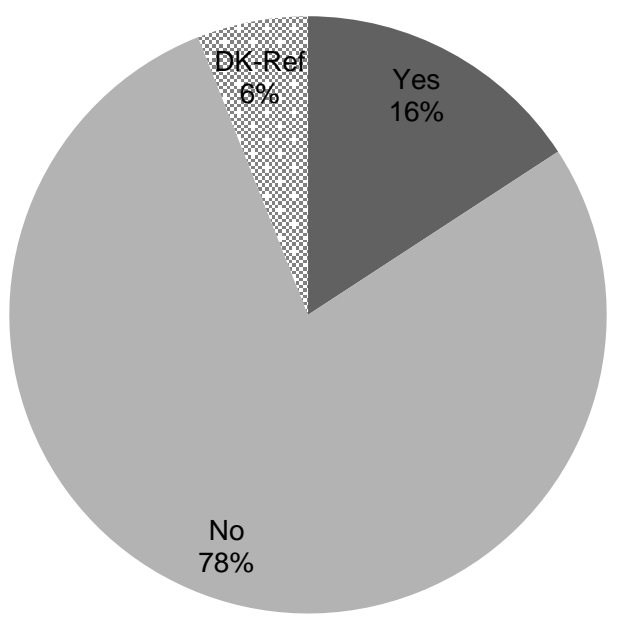

Source: Kolstø (2011)

That is not to say there was consensus among participants or groups on the issue as a whole, but all participants agreed that this policy ought not to be implemented at the time. Respondents universally argued that introducing Cyrillic signs in Vukovar and in Croatia more broadly was not the same. Vukovar as the 'hero city' was frequently raised as the reason for why it was too soon to do so:

NU.T.3 - But we all forget that Cyrillic is also a Croatian alphabet.

NU.T.4 - Yes. And formally as well, but this means something different to them.

NU.T.3 - Something different, that is right. 
NU.T.4 - Those wounds are still too fresh. I do not know, if I were from there, to have lived through it, I do not know how I would react. Currently I have no dilemmas about Cyrillic in Vukovar, just like Istrians have no problems with Italian. And they should have because the Italians occupied them, they depopulated them and everything. But they do not have a problem, 40 years have passed, and they do not have a problem.

NU.T.3 - Yes, yes.

NU.T.4 - Maybe in 50 years in Cyrillic in Vukovar will also not be a problem (dyad with non-urban teachers).

ZG.T.2 - To me it is absurd that, not to mention so recently after the end of the war, in our hero city they are trying to force this. These are political games, but it is absurd. Horrible (dyad with Zagreb teachers).

At times this was seen as a continuation of the war and an act of aggression. It, thereby, fit into the dominant war narrative:

ZA.T.1 - They are pouring salt on people's wounds. I do not know how someone even came up with the idea to put [the signs] right there.

ZA.T.2 - Someone wrote that law and they knew that is could be used in Vukovar. Obviously whoever was making this law was not aware of the geography and population, or it is simply a case of negligence. 
ZA.T.1 - Yes.

ZA.T.2 - The state is at fault (focus group with Zadar war veterans).

SI.V.1 - This is a provocation! They are even waging war in peacetime (focus group with Sisak war veterans).

NU.P.3 - If I were in power, I would put this Cyrillic on two signs, one at the front of [a group of Serbs], one at the back. And then send them over the Danube. Who knows how to swim, who does not (focus group with non-urban pensioners).

The language employed in many of these passages is highly symbolic ('hero city'), accusatory ('this is a provocation'), emotional ('blood from the war has not dried yet') and at times even aggressive ('and then over the Danube'). This highlights the significance of the issue and of the potential for Vukovar and Cyrillic to stir up emotions. As already noted in some of the above passages, the introduction of Cyrillic signs in Vukovar was across all groups seen as the fault of the government and as a political game of some kind. In extreme instances it was seen as a provocation or even an attack from Zagreb:

ZA.V.6 - Cyrillic in Vukovar and Cyrillic in Croatia is not the same thing. Cyrillic in Vukovar is a grenade from Zagreb directed at Vukovar. Zagreb is attacking Vukovar (focus group with Zadar war veterans). 
ZA.P.1 - The blood from the war has not dried yet, from the killing of the people in Vukovar and they are bringing, the Prime Minister is bringing signs with Cyrillic to put on... Even a blind man can see that this is a first class provocation. A provocation (focus group with Zadar pensioners).

All target segments connected the issue of Cyrillic in Vukovar primarily with the Croatian government, at least as the initiator of this effort, and not necessarily with the Serb minority. Overall it was seen as proof of special treatment of the Croatian Serb community. At times they were seen as a victim to party politics and at other times as an ally of the 'infiltrated' government. Some saw it as a method for politicians to hide real problems, such as the economy, while other saw it deeply mired in party politics and blamed either the SDP or the HDZ:

SI.T.2 - This is political.

SI.T.1 - Against the current government.

SI.T.2 - Yes, the current government is using Cyrillic to annul greater problems than Cyrillic.

All agree.

SI.T.1 - It is cheaper to put up 100 signs than to remove loss making companies and to revitalise economic life. 
SI.T.3 - You need to know that here, as soon as big problem arises.

SI.T.2 - A smaller one appears.

SI.T.3 - A media war starts. A new Cyrillic! A new Milošević!

SI.T.1 - Pure politicisation.

All agree

SI.T.3 - Always (focus group with Sisak teachers).

One group of war veterans even saw it as a method for preventing Croats from getting jobs. In this discourse Cyrillic in Vukovar is interpreted as much more than an issue of minority rights, but instead it is seen as a threat to Croatian jobs and as a continuation of the Croatian struggle for independence. Despite that all groups acknowledged Cyrillic was also a Croatian alphabet and formed a part of the Croatian cultural heritage, many nevertheless felt it had been misappropriated and had become dangerous, since it could and was separating people. Given that both the SDP and HDZ were at times blamed for language problems, it is possible that what started as a 1990s HDZ policy of language change has come to be accepted by the majority of the mainstream political spectrum. The Croatian language and associated alphabets may have become one of the primary sources of national and ethnic identification across the majority of Croatian society. 


\section{Conclusion}

Participants in the study reflected the notion that Croatian identity is largely defined by religion and language. These elements are contrasted with the 'other' to Croatian identity, Serbs. Whereas Croats see themselves as Catholic, speaking Croatian and writing in Latin, Serbs and Serbia are seen as Orthodox Christian, Serbian speaking and writing in Cyrillic. This 'other' is also greatly defined by the war narrative, so the Orthodox Church is seen as aggressive, as opposed to the forgiving Catholic Church. Not only were Croats attacked during the war, but also so was the Catholic Church, and general notions of reconciliation are seen as highly based on religion. Croatian identity is, however, based on a much broader set of historical factors and especially the legacies of the Second World War and communism. Together, they help construct how Croats view Serbs.

All participants agreed on only two notions: that Serbs fought on the Croatian side (and do not, therefore, all constitute the enemy) and that Cyrillic signs should not be put up in Vukovar. This exemplifies the core contradiction in the Croat view of Serbs. It is, however, worth noting that teachers stood out in their lack of debate on this topic, whereas war veterans and pensioners discussed it at length. The general impression was that Serbs were not seen as deserving more rights, despite respondents expressing openness towards minorities in general. Much of this dynamic was embodied in discussions about Cyrillic signs in Vukovar. A range of survey results and participants' comments across all groups indicated that ethnic minorities had a right to their own language, but that Serbs could not receive this right in Vukovar at the present time. This created a stark contradiction between general openness towards minorities, but no openness towards Serbs right now, with no indication of when the time might be right. Participants across many groups, in a discourse that featured numerous facets of the war narrative, interpreted Cyrillic in Vukovar as an aggression against Croatia, instead of as an issue of minority rights. This discourse offered no rational 
solutions or visions of the future, instead it was dominated by emotion and, in particular, anger.

This study showed was how a small number of individuals experienced the 1991-1995 conflict, how they remembered it and how this affects their views of the Serb minority in the country. Some are still reliving the war on a daily basis and, alarmingly, this same group also felt their old neighbours, now back, were all potential perpetrators at worst and witnesses at best. Participants overall distrusted institutions meant to protect them and, as if by association, also their Serb neighbours, the Serbian state and the Serbian Orthodox Church. Their memories were not only laced with emotion, they were defined by it.

The ingroup versus outgroup dynamic in this instance has an implication for the Croatian Serb minority in the country, which in the eyes of the majority Croat public continues to be defined by the war narrative. The introduction of Cyrillic signs in Vukovar seems to have had the effect of simultaneously reducing trust in government institutions and making Croats feel threatened by a perceived Serb threat. The implications of this become more dangerous and pronounced in any instance of higher tensions, violence or war, when outgroup membership can become life threatening. 


\section{Bibliography}

Babić, D. 2010. Etnonacionalizam i rat u Hrvatskoj: Teorijski aspekti i istraživanje međunacionalnih odnosa u lokalnim zajednicama [Ethnonationalism and war in Croatia: Theoretical aspects and investigation of interethnic relations in local communities]. Zagreb: Plejada.

Banjeglav, T. 2012. 'Conflicting Memories, Competing Narratives and Contested Histories in Croatia Ultimately, they are best used in', Politička Misao 05: 7-31

Bellamy, A.J. 2003. The formation of Croatian national identity: A centuries-old dream? Manchester: Manchester University Press.

Brentin, D. 2016. 'Ready for the homeland? Ritual, remembrance, and political extremism in Croatian football', Nationalities Papers (web). Available at: http://dx.doi.org/10.1080/00905992.2015.1136996.

Casanova, J. 1994. Public religions in the modern world. London: University of Chicago Press.

Croatian Bureau of Statistics. 2011. Census 2011. Available at: http://www.dzs.hr/Eng/censuses/census2011/results/htm/usp 03 EN.htm.

Council of Europe, Advisory Committee on the Framework Convention for the Protection of National Minorities. 2016. Fourth Opinion on Croatia adopted on 18 November 2015. 30 May 2016.

Dugandžija, N. 2006. Od nacije do reakcije: Nacionalne manjine i nacionalni agnostici [From nation to reaction: Ethnic minorities and ethnic agnostics]. Zagreb: Srpsko kulturno društvo 'Prosvjeta'.

Fishman, J.A. 2006. Do not leave your language alone: The hidden status agendas within corpus planning in language policy. Mahway: Lawrence Erlbaum Associates.

Goldstein, I. 2003. Hrvatska povijest [Croatian history]. Zagreb: Novi Liber.

Hayden, R.M. 1996. 'Imagined communities and real victims: Self-determination and ethnic cleansing in Yugoslavia'. American Ethnologist, 23: 783-801. 
HAZU. 2007. HAZU o hrvatskom jeziku u europskim integracijama [HAZU on Croatian in European integration]. Available at: http://www.hkv.hr/kultura/jezik/962-hazu-ohrvatskom-jeziku-u-europskim-integracijama.html. Accessed: 11 April 2016.

Horvat, R. 2009. Hrvatski identitet [Croatian identity]. Zagreb: Matica Hrvatska.

Ilišin, I. 2011. 'Vrijednosti mladih u Hrvatskoj [Values of young people in Croatia]'. Politička Misao, 48: 82-122.

Ipsos Puls. 2012. Izbori 2011 (Elections 2011). January 2012.

Jakelić, S. 2010. Collectivistic religions: Religion, choice, and identity in late modernity. Farnham: Ashgate.

Joseph, J.E. 2004. Language and Politics: National, ethnic, religious. New York: Palgrave Macmillan.

Jović, D. 2009. 'Croatia after Tudjman: The ICTY and issues of transitional justice'. Chaillot Paper, 116: 13-27.

Kolstø, P.I. 2011. 'Strategies of symbolic nation-building in west Balkan states: Intents and results'. University of Oslo. Available at: http://www.hf.uio.no/ilos/english/research/projects/nation-w-balkan/.

Kordić, S. 2010. Jezik i nacionalizam [Language and nationalism]. Zagreb: Durieux.

Koren, S. 2011. 'Korisna prošlost? Ratovi devetesetih u deklaracijama Hrvatskog sabora [Useful Past? The Wars of the Nineties in the Declarations of the Croatian Parliament]' in T. Cipek (ed), Kultura sjećanja: 1991. povijesni lomovi i svladanje prošlosti [Culture of Memory: 1991. Historical Breaks and Overcoming the Past]. Zagreb: Disput.

Langston, K. and Peti-Stantić, A. 2014. Language planning and national identity in Croatia. London: Palgrave Macmillan.

Leutloff-Grandits, C. 2008. 'Croatia's Serbs Ten Years after the End of the War', in S. P. Ramet, K. Clewing, and R. Lukić (eds.), Croatia since Independence: War, Politics, Society, Foreign Relations. Munich: R. Oldenbourg Verlag: 141-167. 
Lewis, J. 2003. 'Design issues' in J. Ritchie and J. Lewis (eds) Qualitative research practice: A guide for social science students and researchers. London: Sage, 47-76.

MacDonald, D. B. 2002. Balkan holocausts? Serbian and Croatian victim-centred propaganda and the war in Yugoslavia. Manchester: Manchester University Press.

Narodne Novine. 1996. Zakon o općem oprostu [Law on general pardon NN 80/96]. Available at: http://narodne-novine.nn.hr/clanci/sluzbeni/265079.html.

Narodne Novine. 2000. Deklaracija o Domovinskom Ratu [Declaration on the Homeland War]. Available at: http://narodne-novine.nn.hr/clanci/sluzbeni/265079.html.

Narodne Novine. 2006. Deklaracija o Oluji NN [Declaration on Operation Storm]. Available at: http://narodne-novine.nn.hr/clanci/sluzbeni/127530.html.

Oakes, L. 2001. Language and national identity: Comparing France and Sweden. Philadelphia: John Benjamins.

Pavlaković, V. 2008. Red stars, black shirts: symbols, commemorations, and contested histories of World War Two in Croatia. Seattle: The National Council for Euroasian and East European Research

Pavlaković, V. 2014. 'Fulfilling the thousand-year-old dream: Strategies of symbolic nationbuilding in Croatia' in P. Kolstø (ed) Strategies of Symbolic Nation-Building in South Eastern Europe. Farnham: Ashgate,

Peskin, V. and Boduszynski, M. 2003. 'International justice and domestic politics: PostTudjman Croatia and the international criminal tribunal for the former Yugoslavia'. Europe-Asia Studies, 55: 1117-1142.

Prcela, F. 2009. Polog katoličkoga u Hrvatskom identitetu [The role of Catholicism in Croatian identity] in Horvat, R. (ed) Hrvatski identitet [Croatian identity]. Zagreb: Matica Hrvatska.

Ramet, S. 2002. Balkan Babel: The disintegration of Yugoslavia from the death of Tito to the fall of Milošević. 4th ed. Boulder: Westview Press

Richter Malabotta, M. 2004. 'Semantics of war in former Yugoslavia' in B. Busch and H. Kelly-Holmes (eds) Language, Discourse and Borders in the Yugoslav Successor States. Buffalo: Multilingual Matters Ltd. 
Schäuble, M. 2014. Narrating Victimhood: Gender, religion, and the making of place in postwar Croatia. Oxford: Berghahn.

Sells, M. 2003. 'Crosses of Blood: Sacred space, religion, and violence in BosniaHerzegovina'. Sociology of Religion, 64: 309-331.

Smith, A.D. 1991. National identity. London: Penguin.

Spiering, M. 1999. 'The future of national identity in the European Union'. National Identities, 1: 151-159.

Subotić, J. 2015. 'The mythologizing of communist violence'. in L. Stan and N. Nedelsky (eds) Post-communist Transitional justice: Lessons from twenty-five years of experience. New York: Cambridge University Press, 188-210.

Söderström, J. 2010. 'Ex-combatants at the polls: Exploring focus groups and electoral meaning'. Anthropology Matters Journal, 12: 1-16.

Tajfel, H. 1978. 'Social categorisation, social identity and social comparison' in H. Tajfel (ed) Differentiation between Social Groups: Studies in the social psychology of intergroup relations. London: Academic Press.

United Nations, Office of the High Commissioner for Human Rights (OHCHR). 2015. Concluding observations on the third periodic report of Croatia. 30 April 2015.

Zambelli, N. 2010. 'A Journey Westward: A poststructuralist analysis of Croatia's identity and the problem of cooperation with the international criminal tribunal for the former Yugoslavia'. Europe-Asia Studies, 62: 1661-1682.

\footnotetext{
${ }^{1}$ The Homeland War, or Domovinski Rat, was the name given to the 1991-1995 conflict in Croatia by the Tuđmanist narrative of the 1990s (Jović 2009). The term can be interpreted as loaded and only representing the Croat side of the conflict, but it has come to be accepted across most of Croatian society since the 1990s. Today it is commonly used in Croatian politics, culture, education and media. Violence erupted in Croatia in 1991 as the dissolution of Yugoslavia gathered momentum, and lasted until 1995. The conflict encompassed much of Croatia and left 13,000 - 16,000 dead and 500,000 internally or
} 
externally displaced (Goldstein 2003). To this day 2,138 individuals remain missing and many of the over 2 million mines laid in the country are yet to be demined. The conflict in Croatia ended following two Croatian military offensives, Operation Flash and Operation Storm, and the peaceful reintegration of Eastern Slavonia, Baranja and Western Sirmium. The events of the war have since then been the subject of both domestic and international war crimes trials. Serbia and Croatia have also both filed genocide suits against each other at the International Court of Justice.

${ }^{2}$ The Cyrillic alphabet originated in the $9^{\text {th }}$ century with the disciples of Saints Cyril and Methodius, who brought Christianity to the region to south-eastern Europe. In Serbia it forms a large part of the Serbian literary heritage and is today one of the two alphabets used to write standard modern Serbian. In Croatia, on the other hand, only the Latin alphabet is used.

${ }^{3}$ The Croatian city of Vukovar, on the Serbian border in the northeast of the country, was the scene of an 87-day siege by the Yugoslav People's Army (JNA) and Serbian paramilitary forces in 1991. It was the most badly damaged Croatian city during the war and following its fall, a number of war crimes took place in and around it. Prior to the war it was one of the most ethnically diverse parts of Croatia.

${ }^{4}$ For more information on the current status of the Serb minority in Croatia also see the Serb National Council (Srpsko narodno vijeće or SNV) sponsored SNV Bulletin \#6, available at: http://snv.hr/file/attachment/file/bilten6-compressed.pdf

${ }^{5}$ This translates to "Vukovar (in the Latin alphabet), not Vukovar (in Cyrillic)."

${ }^{6}$ Croatian transition from Yugoslav socialism was not to liberal democracy, but to the competitive authoritarian regime of President Franjo Tuđman and the HDZ (Hrvatska Demokratska Zajednica or Croatian Democratic Union). Formal democratic institutions were in place, but they were primarily a means for Tuđman's HDZ of obtaining and exercising political authority, which meant conventional standards of democracy were not met. Tuđman was a Major General in the Yugoslav People's Army (JNA) before becoming a historian in 
1961. He was dismissed from the University of Zagreb and expelled from the League of Communists in 1967 for his nationalist views, specifically for protesting over the unification of the Croatian and Serbian literary languages. He also served two prison sentences in the 1970s for anti-communist and anti-Yugoslav views. Tuđman died in 1999 and the HDZ lost the parliamentary elections in 2000 to a centre-left coalition that began Croatia's process of transition to liberal democracy in earnest.

${ }^{7}$ If a dyad was held with, for example, two additional individual interviews then this is denoted as " $2 ; 1 ; 1$ ".

8 "Za dom, spremni", literally translated to "for the home, ready", was the official salute of the NDH (Nezavisna Država Hrvatska or Independent State of Croatia), the Croatian fascist puppet state during the Second World War. It was led by the Ustasha movement and was responsible for the mass killings of a high percentage of Croatian Serbs, Jews, Roma and political opponents (most notably Partisan fighters). Chief among the incidents of the salute being used in public events was the shouting of the salute by a Croatian national team football player, Josip Šimunić, to a crowd of 25,000 spectators in Zagreb in November 2013. For an overview of the incident and all of the extensive reactions to it (including by media, elites, sports governing bodies and so on) see Brentin (2016).

9 Matica Hrvatska, the institution behind the cited publication, is a non-governmental organisation devoted to Croatian literature and culture. Its aims also include the promotion of Croatian national and cultural identity, and it has played an important role in the history of the standard Croatian language. The extent of its connection to government, despite being an NGO, is debated and discussed later in the paper.

${ }^{10}$ It is important to note that this is not universal among the Croatian public or political elites. In 2009 President Stjepan Mesić had a highly public dispute with the Croatian Catholic Church over the place of Catholic symbols in public institutions.

${ }^{11}$ Narod can be taken to mean people or nation, defined in an ethnic sense. The word is composed of the root rod, from the verb roditi, to give birth (Hayden 1996: 791). By 
definition, this view of the people or the nation only encompasses those of a specific ethnicity. Narod was left in the original Croatian form in excerpts to highlight this.

12 Langston and Peti-Stantić (2014) base this analysis on a model that divides level of language planning into macro (government) and micro (academic institutions; scholarly literature; and, communication with society) levels.

13 "Croatian" Cyrillic is also known as "Bosnian" or "Western" Cyrillic. It was used in BosniaHerzegovina from the $11^{\text {th }}$ until the $18^{\text {th }}$ century and saw resurgence in the $1990 \mathrm{~s}$, amid various nation-building aspirations. It is similar to Serbian Cyrillic, although it was never standardised, and has featured in debates over its historical origins (Bosnian, Croat or Serb).

${ }^{14}$ The idea of Serb preparation was partly based in fact, since arms shipments from the Yugoslav People's Army were prior to the beginning of the conflict, in October 1991, rerouted and left unlocked in Knin so that local Serbs, informed of this in advance, could obtain them (Ramet 2002: 58).

15 Zoran Milanović was President of the left-wing Social Democratic Party of Croatia (Socijaldemokratska partija Hrvatske or SDP) 2007-2016 and Prime Minister of Croatia 2011-2016.

${ }^{16}$ The Law of General Pardon (Zakon o općem oprostu) was passed in 1996, following the end of the war. It protected former members of Serb forces from prosecution, other than for serious human rights violations (Narodne Novine 1996).

${ }^{17}$ This is factually incorrect, since Operation Storm had (at that stage) taken place nearly 20 years prior to the interview.

${ }^{18}$ Novosti is a weekly magazine published by the Serb National Council (SNV). 